\title{
Properties of Yeast Pyruvate Decarboxylase and Their Modi- fication by Proteolytic Enzymes
}

\author{
I. Stability of Decarboxylases from Wild-Type and Mutant Strains
}

\author{
ELLIOT JUNI AND GLORIA A. HEYM \\ Department of Microbiology, The University of Michigan, Ann Arbor, Michigan 48104
}

Received January 27, 1968; accepted March 7, 1968

\begin{abstract}
High concentrations of inorganic phosphate and ammonium sulfate stabilize yeast pyruvate decarboxylase to heating at $60^{\circ}$ for long periods of time in the presence of TPP and $\mathrm{Mg}^{+}$. When heated at $60^{\circ}$ in phosphate concentrations above $1.6 \mathrm{M}$, addition of cofactors is not necessary to stabilize native enzyme. TPP alone, in the absence of divalent cations, is sufficient to stabilize enzyme resolved for cofactors when the enzyme is heated at $60^{\circ}$ in $1.0 \mathrm{M}$ phosphate. High concentrations of TPP are capable of activating resolved enzyme for ability to decarboxylate pyruvate without added divalent cations. Pyruvate decarboxylase present in extracts of a mutant yeast strain was found to be unstable in acetaldehyde-forming capacity but relatively stable in ability to synthesize acetylmethylcarbinol (AMC).
\end{abstract}

Previous studies with yeast pyruvate decarboxylase (EC 4.1.1.1) have led us to conclude that this enzyme catalyzes a two-step reaction (2). In the first step pyruvate combines with TPP, as an enzyme-bound complex, and is decarboxylated to 2-hydroxyethyl TPP (Reaction (1)). Since 2 -hydroxyethyl TPP is a relatively stable compound (3), a second action of this enzyme must involve the splitting of this complex to yield free acetaldehyde (Reaction (2)), as shown in the following reactions.

$$
\begin{aligned}
& \mathrm{CH}_{2}-\mathrm{CO}-\mathrm{COOH}+\mathrm{TPP}- \\
& \mathrm{CH}_{3}-\mathrm{CHOH}-\mathrm{TPP}+\mathrm{CO}_{2} \\
& \mathrm{CH}_{3}-\mathrm{CHOH}-\mathrm{TPP} \rightarrow \mathrm{CH}_{3}-\mathrm{CHO}+\mathrm{TPP}
\end{aligned}
$$

Sum: $\mathrm{CH}_{3}-\mathrm{CO}-\mathrm{COOH} \rightarrow \mathrm{CH}_{3}-\mathrm{CHO}+\mathrm{CO}_{2}$

'This work was supported by grants (RG-9822 and GM-14253) from the United States Public Health Service. A preliminary report of some of these data has appeared (1).

" TPP and AMC are abbreviations for thiamine pyrophosphate and acetylmethylcarbinol (acetoin), respectively.
A minor side reaction also catalyzed by this enzyme is the condensation of enzyme-bound 2-hydroxyethyl-TPP with acetaldehyde to form acetylmethylcarbinol (AMC) (Reaction (4)).

$$
\begin{aligned}
& \mathrm{CH}_{3}-\mathrm{CHOH}-\mathrm{TPP}+\mathrm{CH}_{3}-\mathrm{CHO}- \\
& \mathrm{CH}_{3}-\mathrm{CO}-\mathrm{CHOH}-\mathrm{CH}_{2}+\mathrm{TPP}
\end{aligned}
$$

The present work reports on the properties of pyruvate decarboxylase both from a strain of Bakers' yeast and from a mutant derived from this organism. Enzyme from the mutant strain was characterized by a lowered capacity for acetaldehyde formation (Reaction (3)), relative to AMC formation (Reaction (4)), than was normally found for enzyme from the parent organism. Unlike wild-type pyruvate decarboxylase, which simultaneously loses both acetaldehyde- and AMC-forming ability upon aging, mutant enzyme was shown to have an enhanced instability for the former but not for the latter activity. Some of the factors which stabilize pyruvate decarboxylase have been examined in this communication. 
The peculiar instability of the mutant enzyme has been shown, in the accompanying paper (4), to be the result of a greater activity in this strain of a normally occuring proteolytic enzyme which selectively destroys the second catalytic site of pyruvate decarboxylase.

\section{EXPERIMENTAL PROCEDURE}

Growth of yeast. Saccharomyces cerevisiae, strain LK2G12, was grown in carboys containing 10 liters of a medium consisting of $5 \%$ glucose, $0.3 \%$ proteose peptone, $0.3 \%$ yeast extract, and $0.2 \%$ $\mathrm{KH}_{2} \mathrm{PO}_{4}$. The inoculum was an overnight culture of $100 \mathrm{ml}$ of the same medium seeded with a small amount of yeast paste from a Sabaroud's stock agar slant. After incubation for $24-36$ hours at $30^{\circ}$ without stirring or aeration, the cells were removed by passing the culture through a Sharples centrifuge, washed once with $200 \mathrm{ml}$ of water, spread in a layer approximately $2-3 \mathrm{~mm}$ thick on a sheet of glass, and allowed to air dry at room temperature for 2-4 days. Dried cells (22 grams per 10 liters of medium) were stored in a screw cap bottle at $5^{\circ}$ for not longer than 1-2 weeks.

Growth of bacteria. Zymomonas mobilis (ATTC 10988) was grown without shaking at $30^{\circ}$ in the medium described above for the growth of yeast. Acetobacter suboxydans (ATTC 621) was grown with aeration at $30^{\circ}$ in a medium consisting of $0.5 \%$ glycerol, $1 \%$ proteose peptone, and $1 \%$ yeast extract. Aerobacter aerogenes was grown as previously described (5). Escherichia coli, strain B, was grown as described by Krakow et al. (6) for isolation of glyoxylate carboligase. Micracoccus ureae was grown as previously described (7) for isolation of diacetyl carboligase (8).

Preparation of extracts. Lebedev extracts of yeast (9) were prepared by extracting dried cells with 5-10 volumes of $0.1 \mathrm{M}$ sodium phosphate, $\mathrm{pH}$ 7.0 , at $5^{\circ}$ for 24 hours. Sonic extracts of bacterial suspensions (of wet packed cells) were prepared as previously described (8). Pigeon breast muscle pyruvic oxidase was prepared according to Jagannathan and Schweet (10). Yeast pyruvate decarboxylase was resolved for cofactors as described by Green et al. (11).

Isolation of mutant yeast strain. A thin aqueous suspension of wild-type yeast in a Petri dish was exposed to a germicidal ultraviolet lamp for one minute and the treated suspension was streaked on plates containing Endo agar (Difco) supplemented with $5 \%$ glucose. Normal yeast cells produced redpurple-colored colonies, due presumably to the reaction of aldehydes with the basic fuchsin-sulfite complex in this medium (12). A few mutant colonies, which were small and colorless, were isolated as strains possibly defective in ability to produce acetaldehyde from pyruvate. One of these mutants has been used in the studies described below.

Partial purification of yeast pyruvate decarbox$y$ lase. An outline of the purification procedure used is given in Table I. Dried wild-type cells were extracted with 10 volumes of $0.5 \mathrm{M}$ sodium phosphate, $\mathrm{pH} 7.0$ for 24 hours at $5^{\circ}$. The cells were then removed by centrifugation. Concentrated solutions of TPP and $\mathrm{MgSO}_{4}$ were added to give final concentrations of $1.3 \times 10^{-3} \mathrm{M}$ and $2 \times 10^{-3} \mathrm{M}$, respectively. Heating was accomplished by placing the above solution in a water bath at $65^{\circ}$ and stirring until the temperature had reached $60^{\circ}$. The enzyme solution was then placed in a $60^{\circ}$ water bath where it remained for 30 minutes. The resultant solution, which contained copious masses of heat precipitated protein, was cooled in an ice bath and the denatured protein was removed by centrifugation. To the resulting supernatant solution (Fraction 2) was added sufficient solid $\left(\mathrm{NH}_{4}\right)_{2} \mathrm{SO}_{4}$ to give a solution that was $58 \%$ saturated. The precipitated protein was removed by centrifugation and dissolved in 100 $\mathrm{ml}$ of distilled water (Fraction 3, volume $=108 \mathrm{ml}$ ). An alumina $\mathrm{C}^{\gamma}$ solution $(22 \mathrm{ml}$ containing $23 \mathrm{mg}$ dry weight per $\mathrm{ml}$ ) was centrifuged to precipitate the alumina gel and to this was added the entire solution of the $\left(\mathrm{NH}_{4}\right)_{2} \mathrm{SO}_{4}$ precipitate. After stirring for

TABLE I

Partial Purification of Pyruvate Decarboxylase

\begin{tabular}{|c|c|c|c|c|}
\hline Fraction & Volume (ml) & Protein (mg) & $\begin{array}{c}\text { Specific activity } \\
\left(\mu \text { moles } / \mathrm{mg}_{\text {grotein }}\right. \\
\left(/ 30 \mathrm{~min}^{2}\right)\end{array}$ & Yield $(\%)$ \\
\hline 1. Crude extract & 100 & 657 & 95.3 & 100 \\
\hline $\begin{array}{l}\text { 2. Supernatant solution after } 60^{\circ} \\
\text { for } 30 \mathrm{~min} \text {. }\end{array}$ & 90 & 149 & 285 & 67.8 \\
\hline 3. $0-58 \%$ saturated $\left(\mathrm{NH}_{4}\right)_{2} \mathrm{SO}_{4}$ & 108 & 39 & 728 & 45.3 \\
\hline $\begin{array}{l}\text { 4. Alumina } \mathrm{C}^{\gamma} \text { supernatant solu- } \\
\text { tion }\end{array}$ & 108 & 17.5 & 1,620 & 45.3 \\
\hline
\end{tabular}

a The initial rate of $\mathrm{CO}_{2}$ evolution from pyruvate was determined manometrically. 
10 minutes the alumina $C^{\gamma}$ was removed by centrifugation (supematant solution $=$ Fraction 4). All operations, except for the heating step, were performed at $0-5^{\circ}$.

Determination of Acetaldehyde. Acetaldehyde was determined using a modified Conway assay of the procedure of Burbridge et al. (13). Reaction mixtures, in glass-stoppered tubes, contained $0.0625 \mathrm{M}$ sodium phosphate, $\mathrm{pH} 6.5,1.3 \times 10^{*} \mathrm{M}$ TPP, $1.25 \times 10^{-: 3} \mathrm{M} \mathrm{MgSO}_{4}$, proteose peptone $(4 \mathrm{mg} / \mathrm{ml})$ or bovine serum albumin $(6 \mathrm{mg} / \mathrm{ml})$, and $0.125 \mathrm{M}$ sodium pyruvate in a total volume of $4.7 \mathrm{ml}$. After temperature equilibration at $30^{\circ}$ for 10 minutes, 0.1 $\mathrm{ml}$ of a suitably diluted enzyme solution was added and, after thorough mixing, the tubes were incubated in a $30^{\circ}$ water bath for 30 minutes. The reaction was terminated by addition of $0.6 \mathrm{ml}$ of a solution prepared by mixing equal volumes of $1.0 \mathrm{M}$ $\mathrm{H}_{3} \mathrm{PO}_{4}$ and 1.0 м $\mathrm{KH}_{2} \mathrm{PO}_{4}$. The amount of enzyme added, estimated by manometric assay, should be sufficient to result in the formation of from 0.5 to $5.0 \mu$ moles of acetaldehyde during the 30 minutes incubation. The acidified reaction mixture was cooled in an ice bath and $2.0 \mathrm{ml}$ aliquots were added to the outer rings of cooled $\left(5^{\circ}\right)$ Pyrex Conway dishes, the center wells of which contained exactly $1.0 \mathrm{ml}$ of freshly prepared $0.01 \mathrm{~m}$ semicarbazide IICl. This transfer was made as rapidly as possible to avoid loss of acetaldehyde by volatilization. The cover of the Conway dish was sealed with glycerine and kept in place by a rubber band which held the entire unit fixed to a removable incubator shelf. Conway dishes, set up in duplicate, were incubated at $30^{\circ}$ for 3 hours. After this period, $0.25 \mathrm{ml}$ of the center well fluid was added to $2.75 \mathrm{ml}$ of water in a 1-cm spectrophotometer cuvette and the absorbance at $222.5 \mathrm{~m} \mu$ determined using a reagent blank to set the spectrophotometer to zero absorbance. The net absorbance for $0.1 \mu$ mole of acetaldehyde in a 3.0 $\mathrm{ml}$ volume is 0.380 . A control Conway dish, containing all components of the reaction mixture, except for the enzyme, was also included to correct for a small liberation of acetaldehyde when pyruvatecontaining solutions are acidified.

Figure 1 shows the formation of acetaldehyde with time using the above assay procedure. The actual amount of acetaldehyde formed in the reaction mixture after incubation for 45 minutes was $4.48 \mu$ moles. At this concentration of acetaldehyde $(4.48 \mu$ moles $/ 4.8 \mathrm{ml})$ the reaction rate is somewhat inhibited (Fig. 1). The addition of proteose peptone or bovine serum albumin to the reaction mixture tends to stabilize the dilute enzyme solution. In the Conway assay, an unbuffered solution of semicarbazide $\mathrm{HCl}$ was used since we have shown that the rate of reaction of this reagent with acetaldehyde

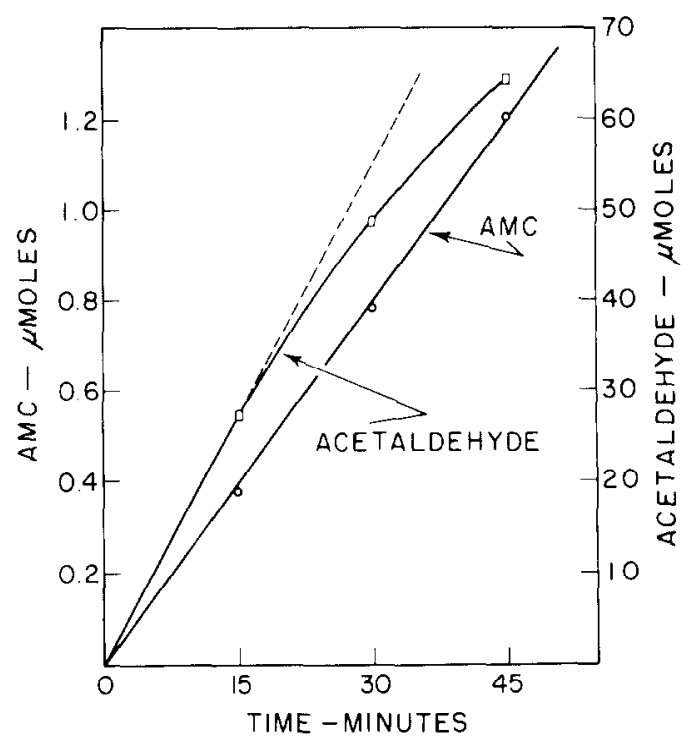

FIc. 1. Linearity with time of assays for acetaldehyde and AMC. Values are those calculated for $0.05 \mathrm{ml}$ of fraction 2 (Table $\mathrm{I}$ ). The actual amounts of enzyme used were $0.0033 \mathrm{ml}$ for the acetaldehyde assay (modified Conway) and $0.075 \mathrm{ml}$ for the $\mathrm{AMC}$ assay.

proceeded more rapidly than when the buffered reagent of Burbridge et al. (13) was used.

The spectrophotometric assay of Holzer et al. (14) has also been used to determine the rate of acetaldehyde formation, but it is somewhat more difficult to maintain precise temperature control using this procedure.

Determination of $A M C$. Reaction mixtures, in glass-stoppered tubes, contained 0.125 м sodium phosphate, pH 6.3, $1.3 \times 10^{-3} \mathrm{M}$ TPP, $1.25 \times 10^{-3}$ M $\mathrm{MgSO}_{4}, 0.125 \mathrm{M}$ sodium pyruvate, and $0.125 \mathrm{M}$ acetaldehyde in a total volume of $1.5 \mathrm{ml}$. After temperature equilibration at $30^{\circ}$ for 10 minutes the reaction was initiated by addition of $0.1 \mathrm{ml}$ of a dilution of pyruvate decarboxylase sufficient to synthesize from 0.5 to $3.0 \mu$ moles of AMC. Reactions were terminated by addition of $0.1 \mathrm{ml}$ of $1.0 \mathrm{~N} \mathrm{H}_{2} \mathrm{SO}_{4}$ and $3.3 \mathrm{ml}$ of water. AMC was determined using $0.5 \mathrm{ml}$ of this acidified mixture according to the method of Westerfeld (15). A control containing all components of the reaction mixture, except for the enzyme, was also included to correct for the small reading produced by pyruvate and acetaldehyde in this test.

Figure 1 shows that the formation of AMC is a linear function of time. The actual amount of AMC formed in the reaction mixture after incubation for 45 minutes in the time curve of Fig. 1 was 1.81 $\mu$ moles. 
Calculation of activity ratio. The activity ratio is defined as the maximum rate of acetaldehyde formation divided by the maximum rate of AMC synthesis. Such acetaldehyde and AMC values are determined by the procedures described and are routinely calculated for $0.1 \mathrm{ml}$ of enzyme solution for a 30 minutes reaction period. The concentrations of substrates used in these assays result in maximum rates for each of the reactions (2).

Protein determination. Protein was determined by spectrophotometric measurement of the turbidity produced after addition of sulfosalicylic acid (16), using a bovine serum albumin standard. This procedure was completely reproducible and correlated with values obtained using the biuret reagent (17) at all levels of enzyme purification.

Chemicals. Acetaldehyde was freshly distilled before preparing a $1.0 \mathrm{~m}$ solution in ice-cold water. Sodium pyruvate was obtained from Nutritional Biochemicals Corp. TPP and bovine serum albumin were obtained from Sigma Chemical Co. Alumina $\mathrm{C}^{\gamma}$ was prepared according to the method described by Colowick (18).

\section{RESULTS}

Extraction and aging of enzymes. Dried cells of mutant strains having possible alterations in pyruvate decarboxylase were extracted in the same manner as wild-type cells. The increase in acetaldehyde-forming ability with time of extraction of wild-type cells fairly well paralleled that for AMC condensation (Fig. 2). Similar curves for one of the mutant

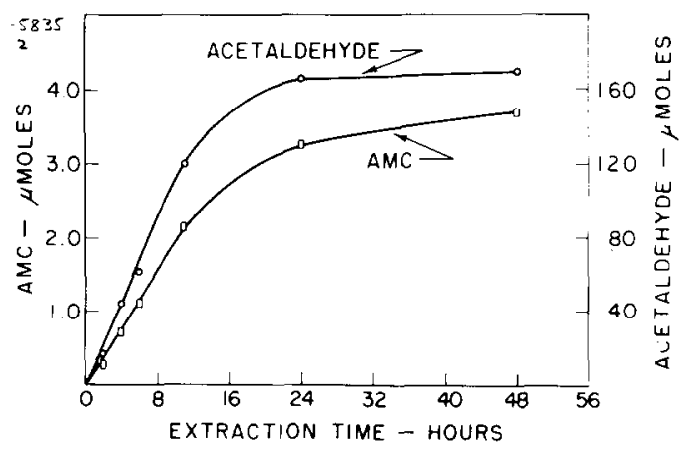

FiG. 2. Extraction of wild-type cells as a function of time at $5^{\circ}$. Dried cells were extracted at $5^{\circ}$ as described in "Experimental Procedure". The values are those calculated for $0.1 \mathrm{ml}$ of wild-type enzyme assayed for 30 minutes. The actual amount of enzyme used in each assay was suitable for the particular procedure employed (see "Experimental Procedurc").

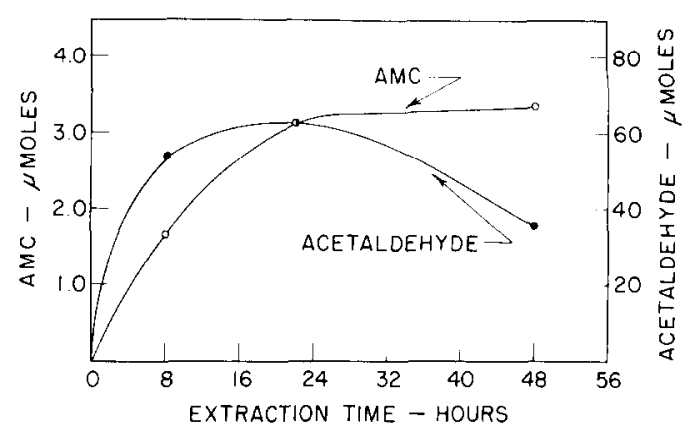

Fig. 3. Extraction of mutant cells as a function of time at $5^{\circ}$. Dried cells were extracted at $5^{\circ}$ as described in "Experimental Procedure". The values are those calculated for $0.1 \mathrm{ml}$ of mutant enzyme assayed for 30 minutes. The actual amount of enzyme used in each assay was suitable for the particular procedure employed (see "Experimental Procedure").

\section{TABLE II}

Aging of Mutant and Wild-Type Yeast ExTRACTS AT $5^{\circ}$

\begin{tabular}{|c|c|c|c|c|}
\hline Extract $^{a}$ & $\begin{array}{l}\text { Incubation } \\
\text { time (hours) }\end{array}$ & $\begin{array}{c}\text { Acetalde- } \\
\text { hyde }^{b}\end{array}$ & $\mathrm{AMC}^{b}$ & $\begin{array}{l}\text { Activity } \\
\text { ratio }\end{array}$ \\
\hline \multirow[t]{4}{*}{ Mutant } & 0 & 64.0 & 2.24 & 28.6 \\
\hline & 16 & 40.3 & 2.14 & 17.9 \\
\hline & 36 & 15.8 & 2.15 & 7.4 \\
\hline & 60 & 1.1 & 1.65 & 0.67 \\
\hline \multirow[t]{3}{*}{ Wild-type } & 0 & 35.6 & 0.64 & 55.6 \\
\hline & 20 & 35.0 & 0.64 & 54.7 \\
\hline & 92 & 25.0 & 0.44 & 56.8 \\
\hline
\end{tabular}

${ }^{a}$ Extracts were prepared by incubating $1 \mathrm{~g}$ of dried cells with $5 \mathrm{ml}$ of $0.1 \mathrm{~m}$ sodium phosphate, $\mathrm{pH} 7.0$, for 18 hours at $5^{\circ}$. The cells were then removed by centrifugation in the cold.

${ }^{b}$ Values in $\mu$ moles $/ 0.1 \mathrm{ml}$ extract $/ 30$ minutes.

- Activity ratio $=$ rate of acetaldehye formation/rate of AMC synthesis.

strains isolated indicate that there was the usual increase in ability to form AMC with time of extraction (Fig. 3). By contrast with wild-type cells, however, acetaldehyde-forming activity of the mutant extract first increased and then fell off during the 48-hour extraction period (Fig. 3).

Enzyme from the mutant strain was aged at $5^{\circ}$ to test the relative stability of the two activities (Table II). Upon incubation in $0.1 \mathrm{M}$ phosphate buffer the rate of acetaldehyde formation decreased rap- 
idly. By contrast, the rate of AMC formation remained essentially constant during 36 hours of incubation. The decarboxylating activity of wild-type enzyme showed a decrease of $30^{\circ}$; during a 92hour incubation period, but there was a corresponding decrease in AMC-forming activity. In this latter case, the activity ratio did not change significantly. It would thus appear that, unlike wildtype enzyme, the mutant decarboxylase showed an unusual kind of instability by virtue of which acetaldehyde-forming activity is lost while the ability to form AMC remains relatively unimpaired.

Stabilization of pyruvate decarboxylase. Pyruvate decarboxylase has been reported to be an unstable enzyme $(19,20)$. In view of the increased instability of mutant enzyme, described above, efforts were made to stabilize the decarboxylase so that it could be purified. The report that inorganic phosphate acts as a competitive inhibitor for pyruvate with yeast pyruvate decarboxylase (14) suggested that phosphate might act in a manner similar to that involved in the commonly observed stabilization of enzymes in the presence of substrate. Since the decar-

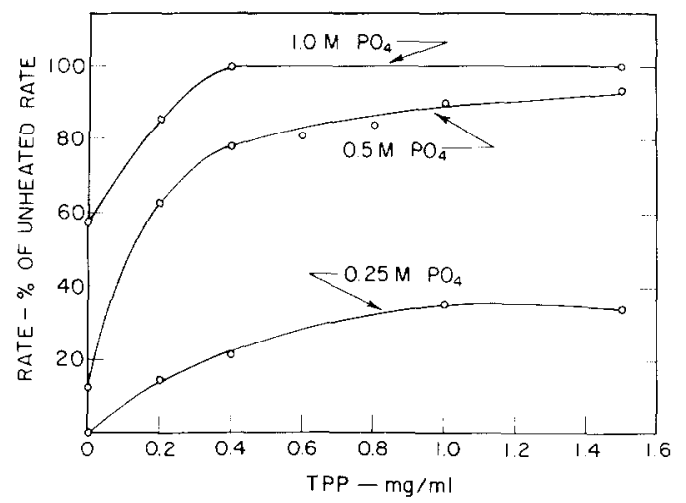

Fro. 4. Residual decarboxylating activity after heating in fixed concentrations of phosphate buffer as a function of TPP concentration. All samples were heated at $60^{\circ}$ for 30 minutes in sodium phos

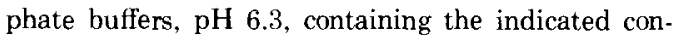
centrations of TPP, $0.002 \mathrm{M} \mathrm{MgSO}_{4}$, and $0.2 \mathrm{ml}$ of crude wild type enzyme per $\mathrm{ml}$ of heating mixture, Suitable dilutions of the heated mixtures were assayed manometrically without removing heat denatured precipitated protein. boxylase requires TPP and a divalent cation such as $\mathrm{Mg}^{-}$for activity, these cofactors were also included in the stabilization studies. It soon became apparent that high concentrations of inorganic phosphate do indeed exert profound stabilization effects, and that TPP and $\mathrm{Mg}^{++}$ are also required.

Fig. 4 shows the recovery of wild-type decarboxylase after heating for a standard test period of 30 minutes at $60^{\circ}$. Although the native enzyme was already almost completely saturated for cofactors (about $85^{\circ} \mathrm{c}$ ), stability to heating is a function of TPP concentration as well as phosphate concentration. Thiamine or thiamine monophosphate could not substitute for TPP and were ineffective in affording protection against heat. The results obtained were independent of the concentration of enzyme used. With crude enzyme preparations only TPP and phosphate were required for stabilization, and added $\mathrm{Mg}^{*+}$ ions had no further influence on stability to heating. When such crude enzyme preparations were passed through a column of Sephadex $\mathrm{G}-25$, to remove small molecules, the cofactor requirements for decarboxylating activity remained the same as that of the untreated enzyme. Gel filtration, however, did result in a preparation that showed a requirement for divalent cations, as well as for TPP, for stabilization to heating (Fig. 5).

When heating was done in $1.0 \mathrm{M}$ phosphate buffer, it was observed that significant protection was obtained even in the absence of added cofactors (Figs. 4 and 5). A study of stability to heating in the presence or absence of added cofactors as a function of phosphate buffer concentration (Fig. 6) revealed that addition of cofactors resulted in profound protective effects when the concentration of phosphate buffer was less than $1.6 \mathrm{M}$. When the concentration of phosphate buffer was maintained above $1.6 \mathrm{~m}$ during heating, it was not necessary to add cofactors to achieve maximum stabilization.

The data in Fig. 7 show that high concentrations of ammonium sulfate can re- 
place phosphate in achieving protection against heating. The $\mathrm{pH}$ optimum for such stabilization to heating is $\mathrm{pH} 5.9$ (Fig. 8). A similar pH optimum was found using phosphate buffer. Arsenate buffers

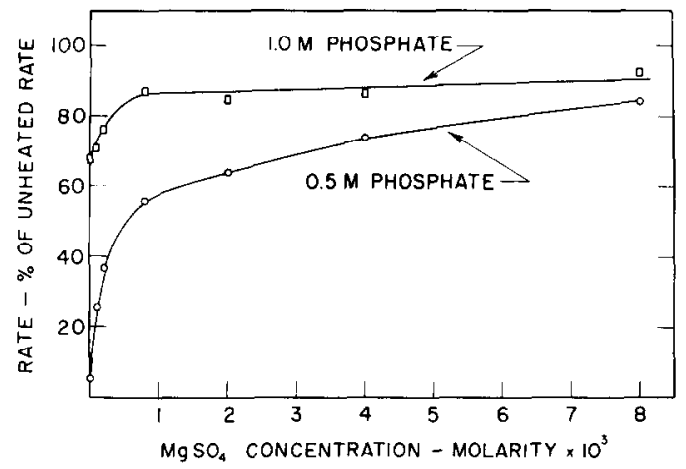

FIG. 5. Residual decarboxylating activity after heating in fixed concentrations of phosphate buffers and TPP as a function of $\mathrm{MgSO}_{4}$ concentration. All samples were heated at $60^{\circ}$ for 30 minutes in sodium phosphate buffers, $\mathrm{pH}$ 6.3, containing the indicated concentrations of $\mathrm{MgSO}_{4}, 2.1 \times 10^{-3} \mathrm{M}$ TPP, and $0.2 \mathrm{ml}$ of enzyme per $\mathrm{ml}$ of heating mixture. The enzyme used was wild-type extract which had been passed through a column of Sephadex G-25 equilibrated with 0.1 M sodium phosphate buffer, $\mathrm{pH}$ 6.3. Suitable dilutions of the heated mixture were assayed manometrically without removing heat denatured precipitated protein.

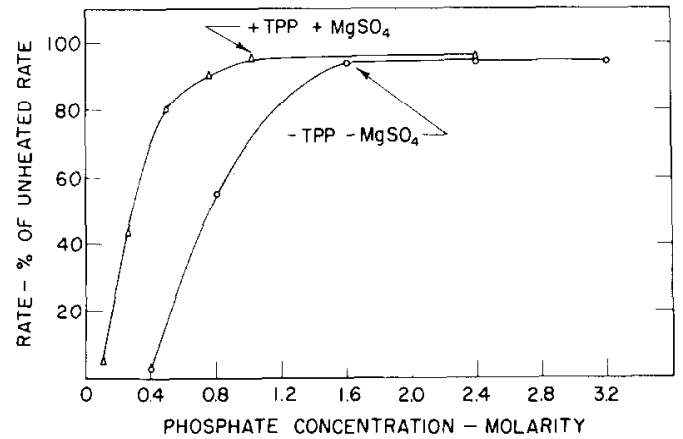

FIG. 6. Residual decarboxylating activity after heating in the presence or ahsence of added cofactors as a function of sodium phosphate concentration. All samples were heated at $60^{\circ}$ for 30 minutes in sodium phosphate buffer, $\mathrm{pH}$ 6.3, containing either $0.002 \mathrm{M} \mathrm{MgSO}_{4}$ and $2.1 \times 10^{-3} \mathrm{M}$ TPP or no other addition. The enzyme was $0.2 \mathrm{ml}$ of crude wild-type extract per $\mathrm{ml}$ of heating mixture. Suitable dilutions of the heated enzymes were assayed manometrically without removing heat denatured precipitated protein.

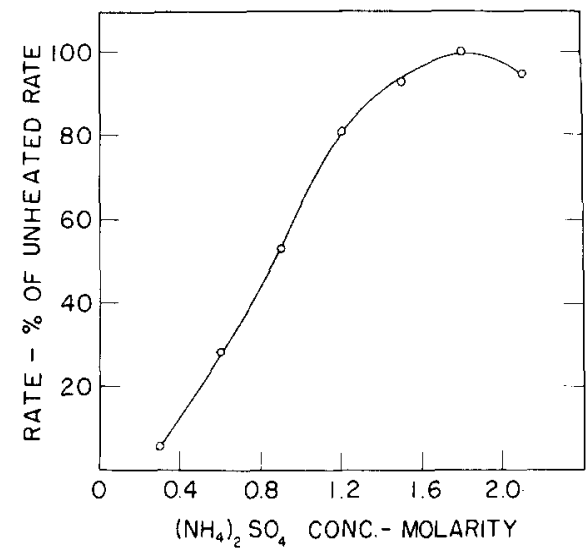

FIG. 7. Residual decarboxylating activity after heating in the presence of cofactors as a function of ammonium sulfate concentration. All samples were heated at $60^{\circ}$ for 30 minutes and contained $0.002 \mathrm{M}$ $\mathrm{MgSO}_{4}, 2.1 \times 10^{-3}$ м TPP, $0.1 \mathrm{ml}$ wild-type extract per $\mathrm{ml}$ of heating mixture, and varying concentrations of ammonium sulfate. Predetermined mixtures of $\left(\mathrm{NH}_{4}\right)_{2} \mathrm{SO}_{4}$ and $\mathrm{NH}_{4} \mathrm{OH}$ were used so that in all cases the final $\mathrm{pH}$ after enzyme addition was between 5.92 and 6.07 . Suitable dilutions of the heated enzymes were assayed manometrically without removing heat denatured precipitated protein.

are also effective stabilizing agents in replacing phosphate. Heating in the presence of $0.1 \mathrm{M}$ phosphate, cofactors and 0.5 м oxalate, nitrate, malonate, or maleate resulted in complete loss of decarboxylating activity.

Stability of enzyme resolved for cofactors. Wild-type decarboxylase was resolved for cofactors using the alkaline ammonium sulfate precipitation procedure of Green et al. (11). Stability to heating of the resolved enzyme in $1.0 \mathrm{~m}$ phosphate buffer was dependent upon addition of cofactors (Table III). It was somewhat surprising to find that addition of TPP alone was able to confer maximum stability to heating of the resolved enzyme preparation. Heating in the presence of $\mathrm{Mg}^{++}$alone or in the absence of both cofactors resulted in complete denaturation (Table III). Preincubation of resolved enzyme with TPP for 15-30 minutes before heating resulted in the recovery of $15-20{ }_{c}$ more active enzyme after the heat treatment than was the 
case when heating was started immediately after addition of TPP.

Activity of resolved enzyme in the absence of added divalent cations. The finding that enzyme resolved for cofactors can be stabilized to heating by addition of a high concentration of TPP in the absence of divalent cations (Table III) suggested that unusually high concentrations of TPP alone might serve to activate resolved enzyme for ability to decarboxylate

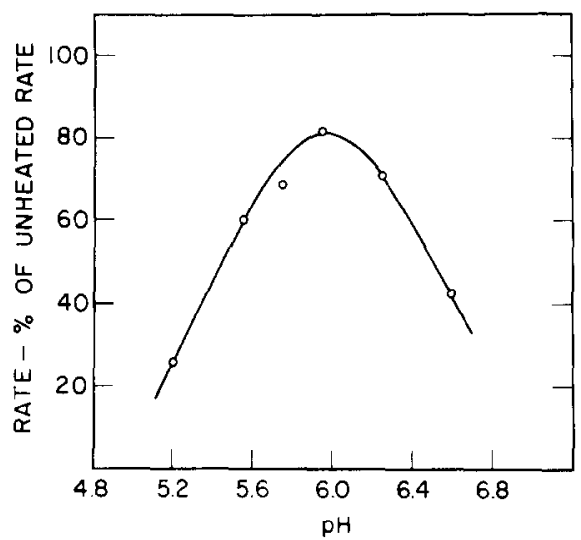

Fig. 8. Residual decarboxylating activity after heating in $1.0 \mathrm{M}$ ammonium sulfate as a function of $\mathrm{pH}$. All samples were heated at $60^{\circ}$ for 30 minutes in $1.0 \mathrm{M}\left(\mathrm{NH}_{4}\right)_{2} \mathrm{SO}_{4}$ solutions containing $2.1 \times 10^{-3}$ M TPP, $0.002 \mathrm{M} \mathrm{MgSO}_{4}$, and $0.1 \mathrm{ml}$ wild-type extract per $\mathrm{ml}$ of heating mixture. The $\mathrm{pH}$ of each sample was adjusted by adding predetermined amounts of $\mathrm{H}_{2} \mathrm{SO}_{4}$ or $\mathrm{NH}_{4} \mathrm{OH}$. Suitable dilutions of the heated enzymes were assayed manometrically without removing heat denatured precipitated protein.

TABLE III

Stability of Resoluned Enzyme to Heating in the Presence and Absence of Cofactors

\begin{tabular}{cc}
\hline Addition prior to heating $^{a}$ & Activity $^{h}(\%)$ \\
\hline $\mathrm{TPP}+\mathrm{Mg}^{++}$ & 81.1 \\
$\mathrm{TPP}$ & 83.7 \\
$\mathrm{Mg}^{++}$ & 0 \\
None & 0 \\
\hline
\end{tabular}

a Resolved enzyme in $1.0 \mathrm{~m}$ sodium phosphate,

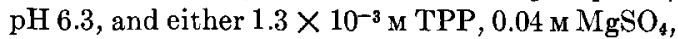
both, or neither was heated at $60^{\circ}$ for 30 minutes.

${ }^{b}$ Activity is given in percent of decarboxylation rate of unheated control assayed in the presence of TPP and $\mathrm{Mg}^{++}$. pyruvate. This was actually found to be the case. Whereas a TPP concentration of $6.25 \times 10^{-6} \mathrm{M}$ was sufficient to give $90 \%$ saturation of the resolved enzyme for decarboxylating activity in the presence of excess $\mathrm{Mg}^{++}$, the activity of the resolved enzyme, supplemented with this same concentration of TTP in the absence of added $\mathrm{Mg}^{++}$, was only $8 \%$. When the TTP concentration was raised to $1.25 \times 10^{-3} \mathrm{M}$ in the absence of $\mathrm{Mg}^{++}$, resolved enzyme showed approximately $70 \%$ of the maximum activity obtained in the presence of saturating levels of both cofactors. A more detailed analysis of this system is presented elsewhere (21).

Stabilization of other TPP enzymes. Several other TPP enzymes were tested for stability to heating at $60^{\circ}$ for $30 \mathrm{~min}$ utes; these included pyruvate decarboxylase from Acetobacter suboxydans, pyruvate decarboxylase from Zymomonas mobilis, glyoxylate carboligase from Escherichia coli, and $\alpha$-acetolactate synthetase from Aerobacter aerogenes. Cofactors (TPP and $\mathrm{Mg}^{++}$) were effective stabilizers against heat denaturation for all of these enzymes, but high levels of phosphate were not required for increased stability. Diacetyl carboligase and pigeon breast muscle pyruvate oxidase were stable to heating at $50^{\circ}$ for 30 minutes but once again this stabilizing effect was independent of phosphate concentration. It would thus appear that the stabilizing effect of high phosphate concentrations is unique for yeast pyruvate decarboxylase among the various TPP enzymes studied.

\section{DISCUSSION}

Previous studies from this laboratory have presented evidence for a two-site mechanism for the action of pyruvate decarboxylase (2). The first site catalyzes the condensation of pyruvate and TPP, which is followed by decarboxylation to form enzyme-bound 2-hydroxyethyl TPP.

The function of the second site was postulated to dissociate this latter complex to free acetaldehyde and enzymebound TPP. Kinetic evidence consistent 
with this hypothesis has been reported by Gruber and Wesselius (22). Further evidence in support of a two-site mechanism for pyruvate decarboxylase has been presented recently by Schellenberger et al. (23).

If pyruvate decarboxylase does possess two distinct catalytic sites, it is conceivable that an altered enzyme could be obtained in which only one of the sites is nonfunctional. Although our efforts to find a mutant having an altered decarboxylase were not successful, we have been able to demonstrate that this enzyme can undergo selective destruction, particularly in extracts from the mutant strain. In terms of the two-site mechanism discussed above, this degradative action appears to involve primarily the second catalytic site of the enzyme. A trivial explanation for the selective destruction of acetaldehyde-forming ability would assume that there is a separate enzyme required for $\mathrm{AMC}$ synthesis and that this enzyme is relatively immune to inactivation. It has been shown fairly conclusively in several laboratories, however, that pyruvate decarboxylase catalyzes both the formation of acetaldehyde and of AMC (see 2).

The impetus to use inorganic phosphate as a stabilizing agent for pyruvate decarboxylase came from the studies of Holzer et al. (14) who had reported that phosphate is a competitive inhibitor for pyruvate decarboxylation. Although inorganic phosphate does protect the decarboxylase from heat denaturation quite effectively (Figs. 4 and 6), the results of the experiments presented in the accompanying paper (4) lead us to conclude that the primary stabilizing action of inorganic phosphate consists of the inhibition of destructive proteolytic enzymes.

The finding that TPP alone, in the absence of divalent cations, was sufficient to stabilize resolved pyruvate decarboxylase in the presence of $1.0 \mathrm{M}$ phosphate buffer (Table III) implied that TPP could combine with resolved enzyme in the absence of a divalent cation. Further ex- periments, reported above, showing that high levels of TPP alone do indeed activate resolved enzyme for ability to decarboxylate pyruvate, confirm this implication. Although it has been assumed (11) that divalent cations function by binding TPP to the enzyme, it is also possible that these ions act in a different manner. One explanation consistent with knowledge of the cofactor interactions of pyruvate decarboxylase is the postulate that divalent cations react with TPP to form a complex that now has a conformation suitable for interaction with apodecarboxylase. When abnormally high concentrations of TPP are used, it is possible that a sufficiently large number of TPP molecules are already in the proper conformation for reaction with apodecarboxylase. Such an interpretation helps explain the findings of other workers that nearly all resolved TPP enzymes have some activity in the presence of added TPP in the absence of divalent cations $(11,24,25,26,27)$. For the case of wheat germ pyruvate decarboxylase, Singer and Pensky (24), showed that resolved enzyme had $23 \%$ of the maximal activity in the presence of a low concentration of TPP alone. Detailed spectral analysis of this enzyme and the buffer used in the assay failed to reveal a significant concentration of divalent cations. Horecker et al. (28) have demonstrated that resolved liver transketolase is fully activated with TPP alone, addition of divalent cations having no effect on the activity of the enzyme. This result is completely different from that for resolved spinach transketolase where divalent cations are required in addition to TPP to fully activate this enzyme (28). The studies of Datta and Racker (29), with yeast transketolase, have shown that previous exposure of resolved enzyme to TPP, which did not serve to form an active enzyme, made it impossible to obtain full activity upon subsequent addition of divalent cations. The authors suggest (29) that TTP alone may combine improperly with the enzyme and that this combination may prevent the catalytically active combination from 
taking place upon subsequent addition of divalent cations. The nature of the binding of TPP to enzymes is considered more fully in another publication (21).

Although the function of high concentrations of inorganic phosphate in stabilizing pyruvate decarboxylase appears to be concermed primarily with the inhibition of destructive proteolytic enzymes (4), the data presented above also suggest other possible actions of phosphate in this system. The requirement for high concentrations of TPP, in addition to phosphate, for stability to heating (Fig. 4), implies that heating tends to dissociate TPP-enzyme complex, which is required for such stability (Table III). High levels of TPP would thus tend to keep the decarboxylase saturated for cofactor. When heating was done in the presence of phosphate concentrations above $1.6 \mathrm{M}$, however, crude enzyme, which had been shown to be partially resolved for TTP, was fully protected (Fig. 6). This result supports the concept that high levels of phosphate prevent dissociation of cofactors. It certainly must be the case that TPP does not dissociate from the enzyme under these latter conditions since the amount of TPP bound to enzyme is not sufficient to resaturate resolved enzyme when added back to such preparations $(11,30)$. Another possible protective function of high levels of phosphate would be inhibition of the acid phosphatase, which has been shown to be present in yeast and capable of hydrolyzing TPP to thiamine and inorganic phosphate (31). If this phosphatase also destroys enzyme-bound TPP at high temperatures the stabilizing effects of phosphate and TPP would be much better explained.

There are numerous published reports dealing with the purification of yeast pyruvate decarboxylase. The greatest purification achieved to date (35-fold) has been reported recently by Ullich et al. (32). Although a homogenous preparation was obtained, the overall yield was only $0.7 \%$. The molecular weight of the enzyme was estimated to be 175,000 and evidence was presented for the occurrence of four binding sites for TPP per enzyme molecule. The molecular weight of wheat germ pyruvate decarboxylase has been reported to be greater than one million (24).

\section{REFERENCES}

1. Juni, E., and Heym, G. A., Bacteriol Proc. p. 95 (1964).

2. Juni, E., J. Biol. Chem. 236, 2302 (1961).

3. Holzer, H., and Beaucamp, K., Biochem. Biophys. Acta 46, 225 (1961).

4. Juni, E., And Heym, G. A., Arch. Biochem. Biophys. 127, 89 (1968).

5. Juni, E., Methods Enzymol. 1, 471 (1955).

6. Krakow, G., Barkulis, S. S., and Hayashi, J. A., J. Bacterivl. 81, 509 (1961).

7. Juni, E., And Heym, G. A., J. Bacteriol. 71, 425 (1956).

8. Jun, E., AND HeYM, G. A., J. Bacteriol. 72, 746 (1956).

9. Neuberg, C., and Lustig, H., Arch. Biochem. 1, 191 (1942).

10. Jagannathan, V., and Schweet, R. S., J. Biol. Chem. 196, 551 (1952).

11. Green, D. E., Herbert, D., and Subrahmanyan, V., J. Biol. Chem. 138, 327 (1941).

12. Margolena, L. A., and Hansen, P. A., Stain Technol. 8, 131 (1933).

13. Burbridge, T. N., Hine, C. H., ANd Schick, A. F., J. Lab. Clin. Med. 35, 983 (1950).

14. Holzer, H., Schultz, G., Villar-Palasi, C., ANd Juntgen-Sell, J., Biochem. Z. 327, 331 (1956).

15. Westerfeld, W. W., J. Biol. Chem. 161, 495 (1945).

16. Layne, F., Methods Enzymol. 3, 447 (1957).

17. Itzhaki, R. F., and Gill, D. M., Anal. Biochem. 9, 401 (1964).

18. Colowick, S. P., Methods Enzymol. 1, 90 (1955).

19. Schoenebeck, O., And Neuberg, C., Biochem. $Z$. 273, 330 (1934).

20. Melnick, J. L., and Stern, K. G., Enzymologia 8, $129(1940)$.

21. Morey, A. V., and Juni, E., J. Biol. Chem. 243, 3009 (1968).

22. Gruber, M., and Wesseluus, J. C., Biochim. Biophys. Acta 57, 171 (1962).

23. Schellenherger, A., Muller, V., Winter, K., and Hubner, G., Z. Physiol. Chem. HoppeSeyler's 344, 244 (1966).

24. Singer, T. P., and Pensky, J., J. Biol. Chem. 196, 375 (1952).

25. Dolin, M. I., and Gunsalus, I. C., J. Bacteriol. 62, 199 (1951). 
26. King, T. E., and Cheldelin, V. H., J. Biol. Chem. 30. Kubowitz, F., and Lüttgens, W., Biochem. Z. 208, 821 (1954). 307, 170 (1941).

27. LeavitT, R. I., and Umbarger, H. E., J. Biol. Chem. 236, 2486 (1961).

28. Horecker, B. L., Smyrniotis, P. Z., and Klenow, H., J. Biol. Chem. 205, 661 (1953).

29. Datta, A. G., and Racker, E., J. Biol. Chem. 236, 617 (1961).

31. Westenbrink, H. G. K., van Dorp, D. A., GruBer, M., ANd Veldman, H., Enzymologia 9, 73 (1940).

32. Ullrich, J., Wittorf, J. H., and Gubler, C. J., Biochim. Biophys. Acta 113, 595 (1966). 